\title{
Treatment of Leprosy with Rifampicin and Isoprodian (L73A)
}

\author{
J. TERENCIO DE LAS AGUAS \\ Sanatorio de Fontilles, Alicante, Spain
}

\begin{abstract}
A total of 27 patients with lepromatous leprosy were treated, 13 with rifampicin, $600 \mathrm{mg}$ per day, and 14 with rifampicin $600 \mathrm{mg}$ per day plus Isoprodian, 2 tablets per day. Clinical improvement was excellent in both groups, bacteriological improvement not so good, as judged by the Morphological and Bacteriological Indices. It was greater in the first group, which had treatment for a longer period.

In general, tolerance was excellent. Reactions occurred in both groups, but were more frequent in the second.
\end{abstract}

The present study was made on two groups of patients.

\section{Group I Rifampicin}

The first group consisted of 13 patients, 12 male and 1 female. Seven patients were very advanced in their disease, and after many years of treatment with sulphone had relapsed, mainly as a result of stopping treatment. Six patients were in the early stages of their disease, and had had no treatment. All 13 patients were strongly positive bacteriologically. They were all treated with rifampicin only, $600 \mathrm{mg}$ per day, and were observed from 2 to 37 months. Results are tabulated as follows.

\begin{tabular}{|c|c|c|c|c|c|}
\hline $\begin{array}{l}\text { Case } \\
\text { No. }\end{array}$ & $\begin{array}{l}\text { Period of } \\
\text { treatment }\end{array}$ & $\begin{array}{c}\text { Results of } \\
\text { bacteriology }\end{array}$ & $\begin{array}{l}\text { Clinical } \\
\text { results }\end{array}$ & Reaction & Tolerance \\
\hline 1 & 37 months & Mucus negative & Excellent & 2 & Good \\
\hline 2 & 30 months & Nil & Good & 3 & Good \\
\hline 3 & 18 months & Reactivation & Good & 2 & Good \\
\hline 4 & 17 months & Nil & Good & $\mathrm{Nil}$ & Good \\
\hline 5 & 16 months & Slight improvement & Excellent & $\mathrm{Nil}$ & Good \\
\hline 6 & 16 months & Slight improvement & Excellent & 1 & Good \\
\hline 7 & 15 months & Slight improvement & Passable & 3 & Good \\
\hline 8 & 15 months & Slight improvement & Excellent & 2 & Good \\
\hline 9 & 14 months & Slight improvement & Good & 3 & Good \\
\hline 10 & 14 months & Slight improvement & Good & Nil & Good \\
\hline 11 & 11 months & Mucus negative & Good & Nil & Good \\
\hline 12 & 12 months & Slight improvement & Slight & Nil & Good \\
\hline 13 & 2 months & $\mathrm{Nil}$ & Slight & 1 & Good \\
\hline
\end{tabular}




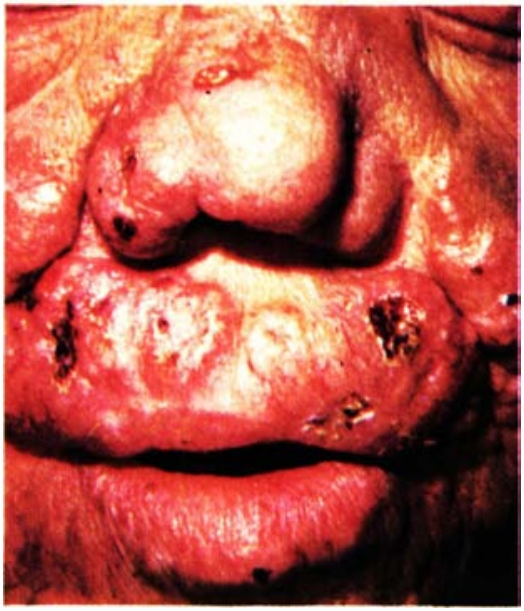

liig. 1. Before treatment.

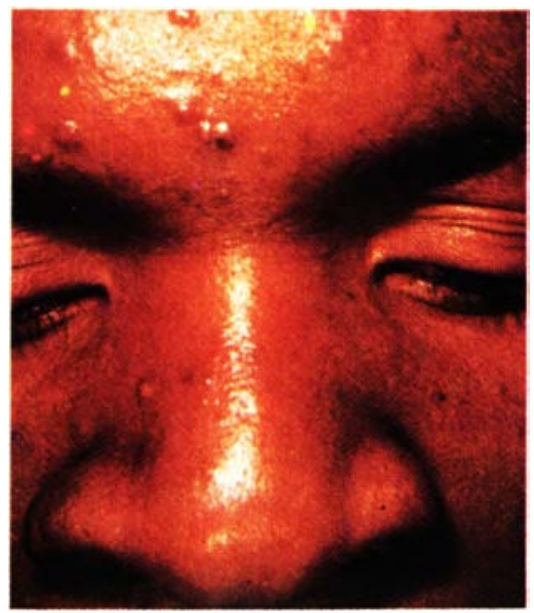

Fig. 3. Before treatment.

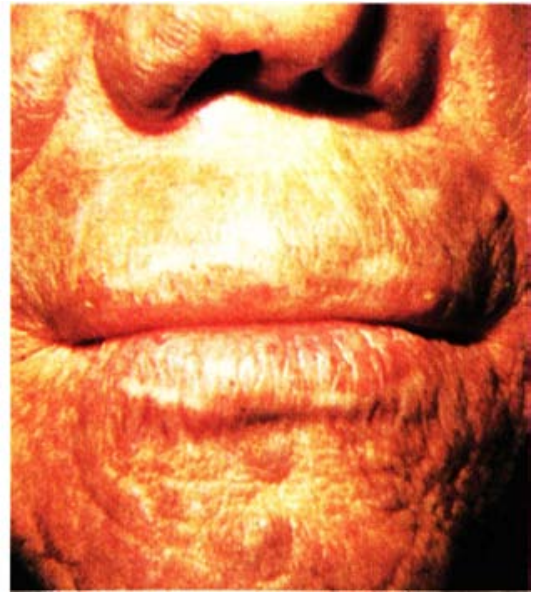

lig. 2. After 6 months of treatment with rifampicin.

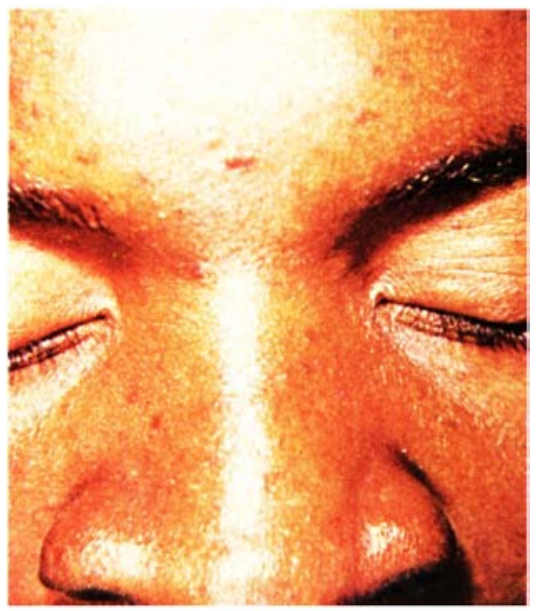

Fig. 4. After 4 months of treatment with rifampicin.

\section{Observations}

Clinical improvement was remarkable in all patients, especially marked in the nodules, the nasal mucosa and the eyes. This improvement was noted between the fourth and tenth week after beginning treatment. Complete resolution of the cutaneous lesions of those patients with very advanced or longstanding leprosy takes a long time. For instance, case No. 1 had treatment for 37 months.

Reduction in bacteriological activity was not as noticeable or as rapid as clinical improvement. The nasal mucosa became negative in two cases; No. 1 after 30 months of treatment, and No. 11 after 8 months. Bacteriological improvement occurred in the majority of cases, being greater in those who had suffered from leprosy for a shorter time and whose clinical lesions were of moderate degree. The 
improvement in the Bacteriological and Morphological Indices was variable. In general, tolerance was good, and no side-effects were observed in relation to the stomach, liver or haemopoietic system. Reactions occurred in 8 patients.

\section{Conclusions}

Rifampicin is an excellent drug with activity on the clinical manifestations, especially nodules, the nasopharyngeal mucosa and in the eye. There is improvement in the neural lesions, but this is not as rapid as in the skin or nasal mucosa.

On the basis of experience with these patients, we can affirm that in contrast to the sulphones, the activity of rifampicin is similar, both in untreated patients and those who have had leprosy for a short time on the one hand, and in patients on the other hand who have had leprosy for a long period or who present in relapse as a result of negligence or deficient sulphone treatment. Most of the in-patients in this series have been early cases. For complete resolution of even such early lesions, the period of treatment needed is likely to be similar to that required with the sulphones.

Reaction is less frequent with rifampicin than with the sulphones. We have given thalidomide during reaction, continuing with the specific treatment, but reducing the dose for some days.

In general, tolerance, including hepatic tolerance, has been excellent. Further observation is necessary to obtain a precise evaluation of the activity of this drug.

The bacteriological improvement in patients treated with rifampicin is not better than in those treated with sulphones. This is the case with patients who have longstanding leprosy with widespread lesions and those who relapse after prolonged sulphone treatment. With a long period of treatment it is possible that resistance might occur.

\section{Group II Rifampicin plus Isoprodian}

This group consisted of 14 patients, 10 male and 4 female, all of them suffering from lepromatous leprosy, and highly positive bacteriologically. These patients were given $600 \mathrm{mg}$ rifampicin and 2 tablets of Isoprodian daily, and kept under observation for from 3 to 9 months. Results may be tabulated as follows.

\begin{tabular}{|c|c|c|c|c|c|}
\hline $\begin{array}{l}\text { Case } \\
\text { No. }\end{array}$ & $\begin{array}{l}\text { Period of } \\
\text { treatment }\end{array}$ & $\begin{array}{c}\text { Results of } \\
\text { bacteriology }\end{array}$ & $\begin{array}{l}\text { Clinical } \\
\text { results }\end{array}$ & Reaction & Tolerance \\
\hline 1 & 9 months & Good & Good & Nil & Good \\
\hline 2 & 6 months & Nil & Good & 2 & Good \\
\hline 3 & 6 months & Nil & Good & 4 & Good \\
\hline 4 & 6 months & Reactivation & Good & 1 & Good \\
\hline 5 & 6 months & Nil & Good & 2 & Good \\
\hline 6 & 6 months & Slight improvement & Good & Nil & Good \\
\hline 7 & 6 months & Reactivation & Good & 6 & Good \\
\hline 8 & 6 months & Slight improvement & Good & 6 & Good \\
\hline 9 & 6 months & Slight improvement & Very good & 1 & Good \\
\hline 10 & 5 months & Nil & Good & 2 & Good \\
\hline 11 & 5 months & Slight improvement & Slight & 3 & Good \\
\hline 12 & 4 months & Nil & $\mathrm{Nil}$ & 3 & Good \\
\hline 13 & 4 months & Nil & Good & 1 & Good \\
\hline 14 & 3 months & Nil & Slight & 1 & Good \\
\hline
\end{tabular}




\section{Conclusions}

Experience with the second group is shorter than with the first, the duration of treatment being only from 3 to 9 months. In general, clinical improvement was remarkable and rapid in 13 patients the only exception being patient No. 12, who has persistent reactional polyneuritis. Bacteriological improvement was less marked than in the first group because of the shorter period of treatment. Tolerance was good in all patients. The number of reactions was higher in this group, all except two suffering from reactional episodes. In some patients the outbreaks were persistent, necessitating thalidomide throughout. We are of the opinion that the frequent reactions were caused by the presence of dapsone in the composition of Isoprodian. In the second group a longer period of observation is necessary before a definite judgment can be given. 